\title{
Model Pembelajaran Cooperative Script Berbantuan Media Strip Story Pada Muatan Pembelajaran IPS di Sekolah Dasar
}

\author{
Andi Sulastri \\ Universitas Hamzanwadi \\ niadianilam@gmail.com
}

\begin{abstract}
Abstrak
Penelitian ini bertujuan untuk mengetahui pengaruh modelpembelajaran cooperative script berbantuan media strip story terhadap hasilbelajar kelas IV pada muatan pembelajaran IPS SDN 11 Pringgabaya Utara. Jenis penelitian yang digunakan adalah penelitianeksperimen dan desain penelitian one group pretest-postest design. Teknik pengumpulan data menggunakan tes. Instrumen penelitian ini adalah tes yang sudah dilakukan pengujian validitas dengan 10 butir soal valid dan uji reliabilitas. Teknik analisis data yang digunakan yaitu uji menggunakan uji normalitas. Uji hipotesis menggunakan uji t dengan taraf signifikan 0,05. Berdasarkan perhitungan untuk uji hipotesis, pengaruh model pembelajaran cooperative script berbantuan media Strip Story terhadap hasil belajar kelas IV pada muatan pembelajaran IPS dengan $t_{\text {hitung }}=8,954$ lebih besar dari $t_{\text {tabel }}$ sebesar 2,086 berarti hipotesis penelitian diterima. Sehingga dapat disimpulkan bahwa ada pengaruh model pembelajaran cooperative script berbantuan media strip story terhadap hasil belajar kelas IV pada muatan pembelajaran IPS SDN 11Pringgabaya Utara.
\end{abstract}

Kata Kunci: Model Pembelajaran, Pembelajaran Cooperative Script, Media Strip Story

\section{Abstract}

This study aims to determine the effect of the cooperative scriptlearning model assisted by the Strip Story media on the fourth-grade learning outcomes in the social studies learning content at SDN 11 Pringgabaya Utara. The type of research used is experimental research and research design One Group Pretest-Postest Design. Data collection techniques using tests. The instrument of this research is a test that has been tested for validity with 10 valid questions and a reliability test. The data analysis technique used in this research is the normality test. Hypothesis testing using t-test with a significant level of 0.05. Based on calculations for hypothesis testing, the effect of the cooperative script learning model assisted by the Strip Story media on learning outcomes for class IV on social studies learning content with $t_{\text {hitung }}=8.954$ greater than $t_{\text {tabel }}$ of 2.086 means the research hypothesis is accepted. So it can be concluded that there is an influence of the cooperative script learning model with the aid of the strip story media on the learning outcomes of grade IV in the social studies learning content at SDN 11 Pringgabaya Utara.

Keywords: Learning Model, Cooperative Script Learning, Media Strip Story 


\section{Pendahuluan}

Perkembangan ilmu pengetahuan dan teknologi telah membawa perubahan yang sangat signifikan terhadap berbagai jenis dimensi kehidupan manusia, baik dalam ekonomi, sosial, budaya, maupun pendidikan. Dalam permendikbud nomor 64 tahun 2013 tentang standar isi pendidikan dasar dan menengah dijelaskan bahwa baik dari proses belajar maupun hasil belajar merupakan upaya untuk meningkatkan mutu pendidikan. Dimana proses belajar mengajar merupakan inti dari kegiatan pendidikan di sekolah. Guru memiliki peran yang sangat penting dalam proses belajar mengajar, di samping sebagai fasilitator dalam pembelajaran siswa juga sebagai pembimbing dan mengarahkan siswa sehingga menjadi manusia yang mempunyai pengetahuan luas baik pengaetahuan, kecerdasan, kecakapan hidup, keterampilan, budi pekerti luhur, dan keperibadian baik (Kemdikbud, 2013).

Berkaitan dengan tujuan pendidikan dasar, Hasan menjelaskan bahwa fungsi dari kurikulum IPS di sekolahdasar adalah membentuk sikap rasional dan bertanggung jawab terhadap masalahmasalah yang timbul akibat interaksi antara manusia dan lingkungannya (Saputra, 2009: 4). Sementara itu tentang materi pembelajaran IPS di sekolah dasar tidak bersifat pengetahuan. Ilmu pengetahuan sosial (IPS) merupakan integrasi dari berbagai cabang ilmu-ilmu sosial seperti: sosiologi, sejarah, politik, geografi, ekonomi, hukum, budaya (Susanto, 2014). Ilmu pengetahuan sosial dirumuskan atas dasar realitas dan fenomena sosial yang mewujudkan satu pendekatan interdisipliner dari aspek dan cabang-cabang ilmu sosial. IPS atau studi sosial itu merupakan bagian dari kurikulum sekolah yang diturunkan dari isi materi cabang-cabang ilmu sosial (Kurniawan, 2014).

Oleh sebab itu supaya proses belajar aktif dan tidak membosankan, guru dalam memberikan pembelajaran idealnya memerlukan bantuan dari alat bantu mengajar seperti model dan media pembelajaran yang dapat menunjang keberhasilan dalam mengajar (Husamah, et al, 2016). Dengan pemanfaatan model dan media pembelajaran khususnya dalam pembelajaran IPS memungkinkan timbulnya interaksi yang efektif antara guru dengan siswa dan antara siswa dengan siswa lainnya. Hal ini dapat mempengaruhi proses belajar mengajar menjadi lebih efektif dalam segala aktivitas belajar (Hayati, 2017).

Salah satu model pembelajaran kooperatif yang dapat diterapkan dalam pembelajaran adalah IPS adalah model pembelajaran cooperative script. Menurut Suprijono (2017: 145) metode cooperative script merupakan metode belajar dimana siswa bekerja berpasangan dan bergantian secara lisan mengihtisarkan/menjelaskan bagian-bagian dari materi yang 
dipelajarinya. Menurut Lambiotte bahwa cooperative script merupakan strategi pembelajaran di mana siswa bekerja secara berpasangan dan bergantian secara lisan dalam mengikhtisarkan bagian-bagian materi yang dipelajari. Strategi ini ditujukan untuk membantu siswa berfikir secara sistematis dan berkonsentrasi pada materi pelajaran (Huda, 2017: 213).

Dari beberapa pendapat di atas dapat disimpulkan bahwa cooperative script merupakan salah satu model pembelajaran yang memungkinkan siswa untuk menemukan ide-ide pokok materi yang disampaikan oleh guru. Untuk lebih memudahkan memahami materi dan aktifits belajar siswa lebih aktif, di perlukan media strip story Adapun salah satu media yang cocok digunakan dalam pembelajaran IPSadalah media strip story. Media strip story merupakan media visualitas yang memerlukan penglihatan siswa dalam menangkap setiap pelajaran.

Penelitian terdahulu yang relevan dengan penelitian ini sekaligus memiliki perbedaan dalam pengunaan model coopertive script dengan berbantuan media adalah hasil penelitian yang dilakukan oleh Wulandari, Suadnyana, \& Darsana (2018) mengunakan model cooperative script berbantuan media strip story pada materi Bahasa Indonesia. Kemudian ada penelitian Fikriyah (2019) lebih fokus menggunakan media strip story dalam pembelajaran IPS. Adapun penelitian yang dilakukan oleh Mahdalena \& Sain (2020) lebih fokus menggunakan model cooperative script tanpa menggunakan media. Ada juga penelitian Meilani \& Sutarni (2016) tentang penerapan model pembelajaran cooperative script untuk meningkatkan hasil belajar membahas tentang administrasi perkantoran di SMK.

Berdasarkan pemaparan di atas maka, tujuan penerapan model pembelajaran cooperative script pada mata pelajaran IPS adalah untuk mempermudah guru dalam menyajikan materi dan mengontrol siswa serta mengatasi keterbatasan ruang sehingga pembelajaran menjadi lebih efektif dan mudah dipahami oleh siswa. Dari hasil penelitian ini diharapkan menjadi rekomensi bagi guru Sekolah dasar meningkatkan kualitas pembelajaran dengan memilih model pembelajaran yang inovatif. Guru juga dapat menggunakan media strip story dan model pembelajaran cooperative script dalam proses pembelajaran IPS ataupun bisa mengembangkannya lebih baik.

\section{Metode Penelitian}

Jenis penelitian yang digunakan dalam penelitian ini adalah metode penelitian eksprimen. Penelitian eksprimen merupakan penelitian yangmemanipulasi atau mengontrol situasi alamiah dengan cara membuat kondisi buatan (artificial condition) sebagai kontrol 
disengaja terhadap objek penelitian dengan memanipulasi kondisi subjek yang diteliti, disertai upaya kontrol yang ketat terhadap faktor-faktor luar dan melibatkan subjek pembanding (Hamzah, 2019: 145). Desain eksperimen yang digunakan dalam penelitian ini yaitu, pre-eksperimental dengan desain penelitian yakni, one group pretest posttest design, dimana pada desain ini terdapat pretest sebelum diberi perlakuan untuk mengetahui hasil belajar siswa. Sebanyak 20 siswa kelas IV Sekolah Dasar Posttes diberikan untuk mengetahui hasil akhir siswa terkait dengan hasil belajar setelah diberikan perlakuan (Sugiyono, 2013: 73).

Instrument pengumpulan data pada penelitian ini menggunakan tes hasil belajar dan dokumentasi. Tes hasil belajar dibagi menjadi dua tahap. Tahap pertama (pretest) perlakuan pada kelompok eksperimen menggunakan model cooperative script berbantuan media strip story. Tahap kedua pengukuran kemampuan akhir IPS siswa (posttest) pada kelompok eksperimen. Cara yang digunakan dalam pengumpulan data dalam penelitian ini adalah dengan cara test yang terdiri dari pretest dan posttest. Teknik analisis data yang digunakan dalam penelitian ini adalah uji normalitas data dengan menggunakan rumus chi-kuadrat dan hipotesis penelitian menggunakan rumus uji t untuk mengetahui uji hipotesis setelah dilakukan uji normalitas dan jika data dinyatakan berdistribusi normal (Jaya, 2019).

\section{Pembahasan}

\section{Deskripsi Data Hasil Belajar Pretest}

Tingkatan pengaruh model pembelajaran cooperative script berbantuan media strip story terhadap hasil belajar IPS kelas IV SDN 11 pringgabaya utara tahun pelajaran 20212022 dilihat pada penerapan model dan media pembelajaran yang sudah diberikan. Berdasarkan hal tersebut diperoleh skor tertinggi dari pretest 68 dan skor terendah 52.

\section{a. Distribusi Frekuensi Data Hasil Belajar Pretest}

Berdasarkan data hasil Belajar pretes diperoleh distribusi frekueensi tertinggi dan terendah dari 20 orang siswa dapat dilihat pada tabel 1 sebagai berikut.

Tabel 1. Distribusi Frekuensi Hasil Belajar Pretest 


\begin{tabular}{ccc}
\hline No & Interval & Frekuensi \\
\hline 1. & $50-53$ & 1 \\
\hline 2. & $54-57$ & 6 \\
\hline 3. & $58-61$ & 6 \\
\hline 4. & $62-65$ & 5 \\
\hline 5. & $66-69$ & 2 \\
\hline & $\sum$ & $\mathbf{2 0}$ \\
\hline
\end{tabular}

Berdasarkan tabel 1 di atas bahwa distribusi frekuensi hasil belajar pretest siswa tertinggi berada pada kelas interval nomor 2 dan 3 yang mempunyai interval antara 54-57 dan 58-61 dengan jumlah siswa sebanyak 6 orang.

\section{b. Diagram Batang Hasil Belajar Pretest}

Berdasarkan data distribusi frekweinsi hasil belajar siswa yang tertinggi dan terendah dari tabel 1 dapat digambarkan pada diagram batang pada gambar 1 sebagai berikut.

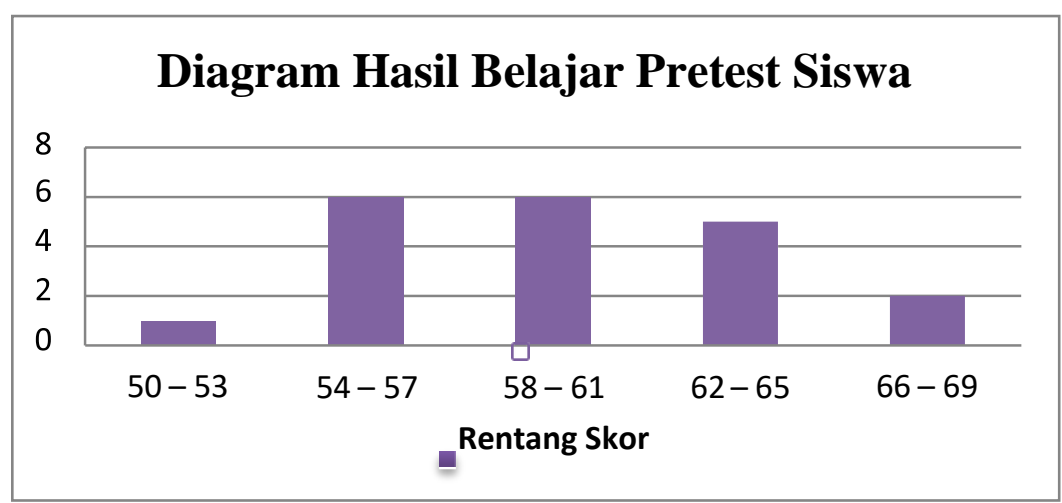

Gambar 1. Diagram Distribusi Frekuensi Hasil Belajar Pretest

Distribusi data variabel hasil belajar siswa dapat dilihat pada tabel 1 dan gambar 2 dengan responden sebanyak 20 siswa dimana rentang nilai 50-53 sebanyak 1 siswa, rentang nilai 54-57 sebanyak 6 siswa, rentang nilai 58-61 sebanyak 6 siswa, rentang nilai 62-65 sebanyak 5 siswa, rentang nilai 66-69 sebanyak 2 siswa.

\section{Deskripsi Data Hasil Belajar Postest}

Tingkatan pengaruh model pembelajaran cooperative script berbantuan media strip 
story terhadap hasil belajar IPS kelas IV SDN 11 pringgabaya utara tahun pelajaran 20212022 dilihat pada penerapan model dan media pembelajaran yang sudah diberikan. Berdasarkan hal tersebut di peroleh skor tertinggi dari posttest 93 dan skor terendah 64 .

\section{a. Deskripsi Data Frekuensi Hasil Belajar Postest}

Berdasarkan data hasil belajar postes diperoleh distribusi frekuensi tertinggi dan terendah dari 20 orang siswa dapat dilihat pada tabel 2 sebagai berikut.

Tabel 2. Distribusi Frekuensi Hasil Belajar Postest

\begin{tabular}{ccc}
\hline No & Interval & Frekuensi \\
\hline 1. & $64-69$ & 2 \\
\hline 2. & $70-75$ & 9 \\
\hline 3. & $76-82$ & 5 \\
\hline 4. & $83-88$ & 0 \\
\hline 5. & $89-94$ & 4 \\
\hline & $\sum$ & $\mathbf{2 0}$ \\
\hline
\end{tabular}

Berdasarkan tabel 2 di atas bahwa distribusi frekuensi hasil belajar siswa tertinggi berada pada kelas interval nomor 2 yang mempunyai interval antara 70-75 dengan jumlah siswa sebanyak 9 orang.

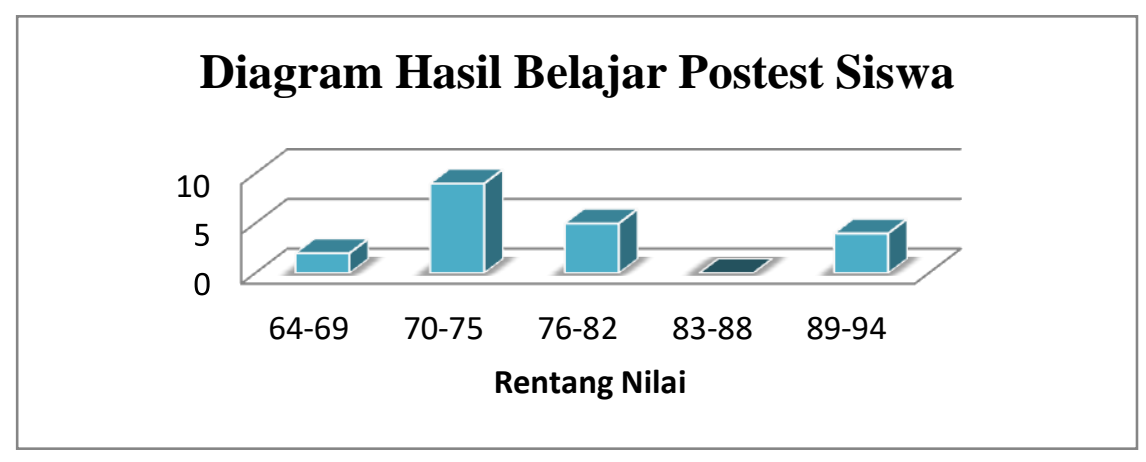

Gambar 2. Diagram Distribusi Frekuensi Hasil Belajar Postest

\section{Diagram Batang Hasil Belajar Postest}

Distribusi data variabel hasil belajar siswa dapat dilihat pada tabel 2 dan Gambar 3 dengan responden sebanyak 20 siswa dimana rentang nilai 64-69 sebanyak 2 siswa, rentang 
nilai 70-75 sebanyak 9 siswa, rentang nilai 76-82sebanyak 5 siswa, rentang nilai 83-88 tidak ada siswa, rentang nilai 89-94 sebanyak 4 siswa.

\section{Analisis Data}

Dari hasil analisis data statistik dengan menghitung rata-rata , varian dan standar deviasi dapat dilihat pada tabel 3 sebagai berikut.

Tabel 3. Distribusi Frekuensi Hasil Pretes

\begin{tabular}{ccccccc}
\hline No & Interval & $\mathbf{F i}$ & $\mathbf{X i}$ & $\mathbf{f i . x i}$ & $\mathbf{x i}-\mathbf{x}$ & $\mathbf{f i}\left(\mathbf{x i}-\mathbf{x}^{2}\right.$ \\
\hline 1 & $46-50$ & 1 & 48 & 48 & -27 & 729 \\
\hline 2 & $51-55$ & 6 & 78.5 & 471 & 3.2 & 61.44 \\
\hline 3 & $56-60$ & 6 & 58 & 384 & -17 & 578 \\
\hline 4 & $61-65$ & 5 & 93.5 & 467.5 & 18 & 648 \\
\hline 5 & $66-70$ & 2 & 68 & 136 & -7 & 98 \\
\hline Jumlah & & $\mathbf{2 0}$ & & $\mathbf{1 1 6 5}$ & & $\mathbf{2 . 1 1 4}$ \\
\hline Rata-rata & & & & & & $\mathbf{5 8}$ \\
\hline Varian & & & & & & $\mathbf{1 1 1 . 2 6}$ \\
\hline StandarD & & & & & $\mathbf{2 . 4 1}$ \\
\hline
\end{tabular}

Berdasarkan hasil tabel 3 distribusi pretest tersebut diperoleh data bahwa frekuensi terbanyak berada pada interval 51-55 dan 56-60 yaitu berjumlah 6siswa. Dengan rata-rata nilai pretest 58, dengan jumlah varian 111.26 dan dan jumlah standar deviasi 2.41. Dari hasil analisis data statistik dengan menghitung rata-rata, varian dan standar deviasi dapat dilihat pada tabel 4 sebagai berikut.

Tabel 4. Distribusi Frekuensi Hasil Postest

\begin{tabular}{ccccccc}
\hline No & Interval & $\mathbf{f i}$ & $\mathbf{X i}$ & $\mathbf{f i . x i}$ & $\mathbf{x i - x}$ & $\mathbf{f i}(\mathbf{x i}-)^{2}$ \\
\hline 1 & $64-69$ & 2 & 98.5 & 197 & 18 & 648 \\
\hline
\end{tabular}




\begin{tabular}{ccccccc}
\hline 2 & $70-75$ & 9 & 72.5 & 652.5 & -8 & 576 \\
\hline 3 & $76-82$ & 5 & 79 & 395 & $-1,5$ & 11.25 \\
\hline 4 & $83-88$ & 0 & 85.5 & 0 & 5 & 0 \\
\hline 5 & $89-94$ & 4 & 91.5 & 366 & 11 & 486 \\
\hline Jumlah & & $\mathbf{2 0}$ & & $\mathbf{1 6 1 0}$ & & $\mathbf{1 7 2 1 . 2 5}$ \\
\hline Rata-rata & & & & & & $\mathbf{8 0 . 5}$ \\
\hline Varian & & & & & $\mathbf{9 0 . 5 7}$ \\
\hline Standar D & & & & & $\mathbf{9 . 5 1}$ \\
\hline
\end{tabular}

Berdasarkan hasil tabel 4 distribusi posttest tersebut diperoleh data bahwa frekuensi terbanyak berada pada interval 70-75 yaitu 9 siswa. Dengan rata-rata nilai posttest 80.5 , dengan jumlah varian 90.57 dan jumlah standar deviasi 9.51 .

\section{Teknik Analisis Data}

\section{a. Uji Normalitas Data Pretest}

Dari hasil uji normalitas data dengan menggunkan rumus chi kuadrat untuk menguji data pretest hasil belajar yang berdistribusi normal sebagai syarat uji hipotesis dapat dilihat pada tabel 5 sebagai berikut.

Tabel 5. Uji Normalitas Data Pretest

\begin{tabular}{cccccc}
\hline Interval & $f_{o}$ & $f_{h}$ & $\left(f_{0}-f_{h}\right)$ & $\left(f_{o_{-}} f_{h}\right)^{2}$ & $\frac{\left(f_{o}-f_{h}\right)^{2}}{n}$ \\
\hline $46-50$ & 1 & 48 & 48 & -27 & $f_{h}$ \\
\hline $51-55$ & 6 & 78.5 & 471 & 3.2 & 61.44 \\
\hline $56-60$ & 6 & 58 & 384 & -17 & 578 \\
\hline $61-65$ & 5 & 93.5 & 467.5 & 18 & 648 \\
\hline $66-70$ & 2 & 68 & 136 & -7 & 98 \\
\hline \multicolumn{7}{c}{ Harga Chi Kuadrat Hitung } & \\
\hline
\end{tabular}

Berdasarkan perhitungan data di atas, ditemukan harga chi kuadrat hitung sebesar 2,166 kemudian dibandingkan dengan harga chi kuadrat tabel dengan derajat kebebasan (dk) $=6-1=5$. Bila dk 5 dan taraf signifikan 5\% maka chi kuadrat tabel $=11,07$. Karena harga chi 
kuadrat hitung lebih kecil dari harga chi kuadrat tabel $(2,166<11,070)$, maka data tersebut berdistribusi normal.

\section{b. Uji Normalitas Data Postest}

Dari hasil uji normalitas data dengan menggunkan rumus chi kuadrat untuk menguji data postest hasil belajar yang berdistribusi normal sebagai syarat uji hipotesis dapat dilihat pada tabel 6 sebagai berikut.

Tabel 6. Uji Normalitas Data Posttest

\begin{tabular}{cccccc}
\hline Interval & $f_{o}$ & $f_{h}$ & $\left(f_{0}-f_{h}\right)$ & $\left(f_{o_{-}} f_{h}\right)^{2}$ & $\frac{\left(f_{o}-f_{h}\right)^{2}}{n}$ \\
\hline $64-69$ & 2 & 98.5 & 197 & 18 & $f_{h}$ \\
\hline $70-75$ & 9 & 72.5 & 652.5 & -8 & 578 \\
\hline $76-82$ & 5 & 79 & 395 & $-1,5$ & 11.25 \\
\hline $83-88$ & 0 & 85.5 & 0 & 5 & 0 \\
\hline $89-94$ & 4 & 91.5 & 366 & 11 & 486 \\
\hline Harga Chi Kuadrat Hitung & & & $\mathbf{5 , 8 1 2}$
\end{tabular}

Berdasarkan perhitungan data di atas, ditemukan harga chi kuadrat hitung sebesar 5,812 kemudian dibandingkan dengan harga chi kuadrat tabel dengan derajat kebebasan $(\mathrm{dk})=6-1=5$. Bila $\mathrm{dk} 5$ dan taraf signifikan 5\% maka chi kuadrat tabel =11,07. Karena harga chi kuadrat hitung lebih kecil dari harga chi kuadrat tabel $(5,812<11,070)$, maka data tersebut berdistribusi normal.

\section{Uji Hipotesis}

Hipotesis penelitian ini dikatakan berhasil. Hal ini dibuktikan dengan hasil perhitungan dari uji $\mathrm{t}$ diperoleh nilai $\mathrm{t}$ untuk variabel pengaruh model pembelajaran cooperative script berbantuan media strip story dengan $t_{\text {hitungsebesar } 8,954 \text { lebih besar }}$

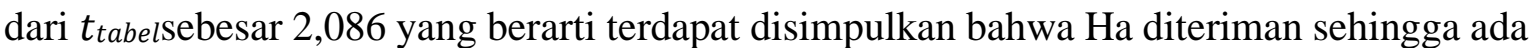
pengaruh model pembelajaran cooperative script berbantuan media strip story terhadap hasil belajar siswa kelas IV SDN 11 Pringgabaya Utara. 


\section{Pembahasan}

Adapun sampel yang digunakan dalam penelitian ini adalah siswa kelas IV yang berjumlah 20 siswa. Penelitian ini menggunakan jenis penelitian eksperimen dimana dalam pelaksanaannya peneliti memberikan perlakuan terhadap sampel. Dalam hal ini peneliti akan menguji pengaruh model pembelajaran cooperative script berbantuan media strip story terhadap hasil belajar siswa kelas IV SDN 11 Pringgabaya Utara. Adapun desain penelitian yangdigunakan dalam penelitian ini yakni, one group pretest posttest design, dimana pada desain ini terdapat pemberian pretest sebelum diberikan perlakuan terhadap sampel untuk mengetahui kemampuan awal siswa terhadap hasil belajar dilanjutkan dengan pemberian posttest untuk mengetahui hasil akhir siswa terkait dengan hasil belajar setelah diberikan perlakuan dengan menggunakan pengaruh model pembelajaran cooperative script berbantuan media strip story terhadap hasil belajar siswa.

Dengan demikian hasil perlakuan dapat diketahui lebih akurat,sehingga lebih mudah membandingkan hasil belajar siswa sebelum diberikanperlakuan dengan sesudah diberikan perlakuan. Selanjutnya teknik yang digunakan peneliti dalam pengumpulan data yakni dengan cara memberikan tes kepada siswa dan melakukan dokumentasi yang dilakukan oleh peneliti selama pembelajaran berlangsung. Sebelum melakukan penelitian, terlebih dahulu peneliti melakukan uji validitas dengan cara membagikan lembaran tes yang terdiri dari 10 butir soal kepada 15 siswa kelas IV SDN 11 diluar responden. Butir soal dinyatakan valid apabila harga rhitung butir soal lebih besar dari thitung. Dari pengujian validitas tersebut diperoleh data bahwa semua soal dinyatakan valid. Kemudian dilanjutkan dengan uji reliabilitas. Bedasarkan perhitungan uji reliabilitas menggunakan rumus Alpha Cronbach dengan butir soal berjumlah 10 dengan jumlah varianbutir 2,55 dan varian total 639,4 maka diperoleh hasil $r_{\mathrm{i}}=0,6611$ Jika dikonsultasikan dengan tabel koefisien korelasi, maka termasuk kedalam reliabilitas tinggi.

Setelah semua data pada pelaksanaan pretest dan posttes terkumpul peneliti selanjutnya melakukan analisis hasil tes. Dalam hasil tes menyatakan rata-rata untuk nilai tes pada pretest sebesar 58, dengan nilai terendah 52 dan tertinggi 68, dengan nilai varian sebesar 30,26 dan nilai standar deviasi sebesar 5,50.Sedangkan rata-rata untuk nilai tes pada posttes sebesar 80, dengan nilai terendah 64 dan tertinggi 93, dengan nilai varian sebesar 90,57 dan nilai standar deviasi sebesar 9,51.

Analisis selanjutnya yaitu pengujian normalitas data. Dari Hasil uji normalitas data 
untuk pretes diketahui bahwa harga Chi kuadrat hitung lebih kecil dari harga chi kuadrat tabel $(2,166<11,07)$, maka dapat dinyatakan bahwa distribusi data Pretest tersebut berdistribusi normal. Selanjutnya untuk hasil uji normalitas data postes diketahui harga Chi kuadrat hitung lebih kecil dari harga Chi kuadrat tabel $(5,812<11,07)$, maka dapat dinyatakan distribusi data Posttest tersebut berdistribusi normal.

Analisis terakhir yaitu pengujian hipotesi. Hasil perhitungan dari uji t diperoleh nilai $t$ untuk variabel pengaruh model pembelajaran cooperative script berbantuan media strip story terhadap hasil belajar siswa dengan $t_{\text {hitung }}$ sebesar 8,954 lebih besar dari $t_{\text {tabel }}$ sebesar 2,086 yang berarti Ha diterima sehingga dapat disimpulkan bahwa terdapat pengaruh positif dan signifikan penggunaan model pembelajaran cooperative script berbantuan media strip story terhadap hasil belajar siswa.

Hasil belajar merupakan salah satu tolak ukur dalam kecerdasan yang dimiliki siswa. Salah satu faktor yang dapat meningkatkan hasil belajar siswa adalah penerapan model pembelajaran dan pemanfaatan media pembelajaran dalam proses belajar yang digunakan oleh guru sehingga dengan penggunaan media yang bervariasi memudahkan siswa dalam memahami materi yang disampaikan oleh guru. Jadi berdasarkan hasil uji hipotesis terdapat pengaruh yang positif dan signifikan menggunakan model pembelajaran cooperative script berbantuan media strip story untuk mengatasi masalah rendahnya hasil belajar IPS (Aritonang, 2008).

Salah satu model pembelajaran kooperatif yang dapat diterapkan dalam pembelajaran adalah model pembelajaran cooperative script. Menurut Suprijono (2017: 145) bahwa cooperative script merupakan metode belajar dimana siswa bekerja berpasangan dan bergantian secara lisan mengihtisarkan/menjelaskan bagian-bagian dari materi yang dipelajarinya. Untuk memaksimalkan penggunaan model pembelajaran tersebut dalam pembelajaran maka perlu di bantu dengan media pembelajaran yaitu media strip story. Dimana strip story adalah bagian-bagian atau potongan kertas yang berisi cerita yang dibagi secara acak kepasa siswa untuk disusun sesuai dengan cerita atau alur cerita yang sudah disiapkan oleh guru (Apriliawati, 2018: 17). Kelebihan dari media strip story adalam pembelajaran yaitu; a) Para siswa lebih aktif di dalam kelas saat proses pembelajaran berlangsung; b) Dengan menggunakan media strip story kegiatan pembelajaran akan lebih menyenangkan dan membuat siswa tidak mudah jenuh/bosan; c) Memberikan kesempatan kepada siswa dalam berbicara untuk menceritakan kembali materi atau cerita yang didapat; 
d) Dapat meningkatkan proses belajar kelompok dan sifat kerjasama sesame kelompok.

Berdasarkan penelitian yang ditulis oleh Wulandari, Suadnyana, \& Darsana (2018), menyimpulkan bahwa pembelajaran dengan model pembelajaran cooperative script berbantuan media Strip Story berpengaruh pada terhadap penguasaan kompetensi bahasa Indonesia. Berhasilnya penerapan model dan media ini diketahui dari adanya pengaruh yang signifikan pada penguasaan kompetensi pengetahuan bahasa Indonesia antara kelompok siswa yang dibelajarkan melalui model dan media tersebut dengan siswa yang tidak dibelajarkan melalui model cooperative script berbantuan media strip story pada siswa kelas IV SD Gugus IV Kuta Selatan. Hal ini menunjukkan bahwa penerapan model cooperative script berbantuan media strip story dapat dikatakan berhasil.

Persamaan penelitian di atas dengan penelitian yang akan diteliti adalah sama-sama menggunakan model cooperative script berbantuan media strip story. Adapun letak perbedaannya terletak pada materi yang akan diteliti. Penelitian relevan di atas menjelaskan kompetensi pengetahuan bahasa Indonesia sedangkan pada penelitian ini meneliti hasil belajar IPS, jadi dapat disimpulkan penggunaan model cooperative scrip dengan berbantuan media strip story dapat di gunakan di berbagai mata pelajaran yang lainnya.

\section{Kesimpulan}

Media strip story dalam pembelajaran IPS SD dapat membantu peran guru sebagai fasilitator dalam proses pembelajaran berlangsung serta siswa dapat saling belajar satu sama lain. Para siswa lebih aktif di dalam kelas saat proses pembelajaran berlangsung. Dengan menggunakan media strip story kegiatan pembelajaran akan lebih menyenangkan dan membuat siswa tidak mudah jenuh/bosan; memberikan kesempatan kepada siswa dalam berbicara untuk menceritakan kembali materi atau cerita yang di dapat dan dapat meningkatkan proses belajar kelompok dan sifat kerjasama sesama kelompok. Berdasarkan hasil penelitian dan pembahasan tersebut dapat disimpulkan bahwa ada pengaruh positif dan signifikan dari penerapan model pembelajaran cooperative script berbantuan media strip story terhadap hasil belajar IPS siswa kelas IV SDN 11 Pringgabaya Utara.. Hal ini dibuktikan dengan

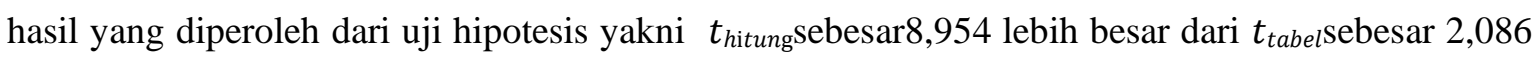
yang berarti disimpulkan bahwa Ha diterima.

\section{Daftar Rujukan}

Apriliawati, H. (2018). Efektivitas Penggunaan Strip Story Terhadap Kemampuan Berbicara 
Siswa Kelas X SMAN 1 Rejotangan Tulungagung. Skripsi. IAIN Tulungagung.

Aritonang, K. T. (2008). Minat dan Motivasi Dalam Meningkatkan Hasil Belajar Siswa. Jurnal Pendidikan Penabur, 7(10), 11-21.

Fikriyah, Q. (2019). Pengaruh Media Strip Story Terhadap Hasil Belajar Peserta Didik Kelas V MI EL-Ziyan Pada Mata Pelajaran IPS. Skripsi. Fakultas Ilmu Tarbiyah \& Keguruan Uin Syarif Hidayatullah.

Hamzah. (2019). Metode Penelitian dan Pengembangan. Malang: CV. Literasi Nusantara.

Hayati, Sri. (2017). Belajar \& Pembelajaran Berbasis Cooperative Learning. Magelang: Graha Cendekia.

Huda, M. (2017). Model-model Pengajaran dan Pembelajaran. Yogyakarta: Pustaka Pelajar.

Husamah, Pantiwati, Y., Restian, A., \& Sumarsono, P. (2016). Belajar dan Pembelajaran. Malang: UMM Press.

Jaya, I. (2019). Penerapan Statistik Untuk Penelitian Pendidikan. Jakarta: Prenadamedia Group.

Kemendikbud, (2013). Permendikbud Nomor 64 Tahun 2013 tentang Standar Isi Pendidikan Dasar dan Menengah.

Kurniawan. (2014). Pembelajaran Terpadu Tematik. Bandung: Alfabeta.

Mahdalena, S., \& Sain, M. (2020). Meningkatkan Hasil Belajar Siswa Melalui Penerapan Model Pembelajaran Cooperative Script Pada Mata Pelajaran Ilmu Pengetahuan Sosial Kelas VA Siswa Sekolah Dasar Negeri 010 Sungai Beringin. Asatiza: Jurnal Pendidikan, 1(1), 118-138.

Meilani, R., \& Sutarni, N. (2016). Penerapan Model Pembelajaran Cooperative Script Untuk Meningkatkan Hasil Belajar. Jurnal Pendidikan Manajemen Perkantoran (JPManper), 1(1), 176-187.

Saputra, T. A. (2009). Pembelajaran IPS Di Sekolah Dasar Berbasis pembelajaran Tematik. EduHumaniora| Jurnal Pendidikan Dasar Kampus Cibiru, 1(2).

Sugiyono. (2013). Metode Penelitian Kuantitatif, Kualitatif dan R\&D. Bandung: Alfabeta.

Suprijono, A. (2017). Cooprative Learning Teori \& Aplikasi Paikem. Yogyakarta: Pustaka Pelajar.

Susanto. (2014). Pengembangan Pembelajaran IPS di Sekolah Dasar. Jakarta: Prenadamedia Group.

Wulandari, L. P. A., Suadnyana, I. N., \& Darsana, I. W. (2018). Pengaruh Model Pembelajaran Cooperative Script Berbantuan Media Strip Story Terhadap Kompetensi Pengetahuan Bahasa Indonesia, Indonesian Journal of Educational Research and Review, 1(2). 